\title{
Utfordringer og muligheter i møtepunktet mellom yrkesfaglærerutdanningen og praksis i videregående skole
}

\author{
(Challenges and opportunities in the meeting point between \\ vocational teacher education and upper secondary school practice)
}

\author{
Jorunn Dahlback, Hanne Berg Olstad, Ann Lisa Sylte, Anne-Catrine Wolden ${ }^{1}$ \\ OsloMet - Storbyuniversitetet, Norge (jdahlbac@oslomet.no)
}

\begin{abstract}
In 2020 a new school reform will be implemented in Norway, with required vocational specialisation the first year in upper secondary school. The aim of this article is to analyse challenges and opportunities in the meeting point between vocational teacher education in Design and Craft (YFL) and the field of practice, to meet the required vocational specialisation. Previous research has established that there is a relevance issue in vocational education and training (VET). There are challenges with a lack of coherence between the vocational specialisation in VET and the work-life needs for competence. The research focus is about coherence between the upper secondary schools' didactical organization in VET programmes for Design and Craft and the content of YFL. The research methods are interviews with VET teachers, and qualitative questionnaires and interviews with YFL students in the period 2014-2017. The results show that there is partly low coherence between the teacher's didactical organization and choice of teaching methods, and the content in YFL. The lack of coherence can be addressed to VET teachers' focus on discipline-based VET with a lack of early vocational specialisation. However, the results also show new opportunities for how to develop more relevant VET for the work-life needs for competence, which is coherent to the occupational-related content in YFL.
\end{abstract}

Keywords: coherence, relevance, occupational-related content and teaching methods, vocational-didactics, subject-didactics

NJVET, Vol. 8, No. 3, 57-77 Peer-reviewed article doi: 10.3384/njvet.2242-458X.188357 


\section{Innledning}

I norsk yrkesopplæring kommer det i 2020 ny tilbudsstruktur med revidering av læreplanene (Utdanningsdirektoratet [Udir], 2018). Bakgrunnen er kritikk mot dagens tilbudsstruktur i læreplanverket Kunnskapsløftet (Kunnskapsdepartementet [KD], 2006), som har ført til svak yrkesretting og til dels manglende yrkesrelevans (Aspøy, Skinnarland \& Tønder, 2017; Meld. St. 28 (2015-2016); Vibe, Frøseth, Hovdhaugen \& Markussen, 2012). Hovedmodellen i norsk yrkesfagopplæring har siden skolereformen i 1994 (Reform-94) vært to år i skole etterfulgt av to års læretid i bedrift. Dagens yrkesopplæring har åtte brede utdanningsprogram (KD, 2006). I denne artikkelen tar vi utgangspunkt i empiriske eksempler fra første året $\mathrm{i}$ utdanningsprogrammet Design og håndverk i videregående skole (Vg1 DH). Dette er et av de bredeste utdanningsprogrammene som rekrutterer til 52 svært ulike yrkesfag, som for eksempel frisør, blomsterdekoratør, møbelsnekker, og gullsmed (Udir, 2006, 2016). Formålet med opplæringen er å gi elevene praktisk erfaring med produksjonsprosesser og grunnleggende arbeid innen DH-yrkene (KD, 2006). Evalueringer viser at arbeidsgiverne opplever det faglige nivået i utdanningen har blitt svekket, og lærerne er usikre på hva som er formålet med $\mathrm{Vg} 1 \mathrm{DH}$, og hva som er utdanningsprogrammets identitet (Udir, 2016, s. 63). Kritikken gjelder i stor grad strukturen i dagens yrkesopplæring, med stor bredde og lite rom for faglig fordypning (NIFU, 2015, s. 65).

I den nye tilbudsstrukturen 2020, som er en fornyelse av Kunnskapsløftet 2006, stilles det krav om tidligere yrkesspesialisering med mål om en mer konsistent videregående opplæring (Udir, 2018). Hensikten er å skape bedre yrkesrelevans i tråd med elevens, arbeidslivets og samfunnets behov. Utdanningsprogrammet DH blir delt i to, det ene med seks yrkesfag, og det andre med 43 tradisjonshåndverksfag (Udir, 2018). Det minste av disse vil få felles opplæring på Vg1 i svært ulike yrker som; interiørkonsulent, utstillingsdesigner, blomsterdekoratør og frisør. Dermed vil også den nye strukturen gi utfordringer med kravet om tidlig yrkesspesialisering.

Yrkesfaglærerutdanningen (YFL) i DH vektlegger profesjonsretting i tråd med samfunnets, praksisfeltets og studentenes behov for kompetanse (KD, 2013). Som et ledd i profesjonsrettingen gjennomfører YFL-studenter pedagogisk praksis på Vg1 DH. Både lærerutdannere og studenter erfarte store utfordringer med sammenhengen mellom innholdet i YFL, og praksisfeltets didaktiske organisering av opplæringen ved Vg1 DH.

Tidligere forskning peker på viktigheten av profesjonsretting, relevans og koherens i yrkes- og profesjonsutdanninger (Canrinus, Bergem, Klette \& Hammerness, 2017; Hiim, 2015; Mausethagen \& Smeby, 2017). Det er imidlertid lite forskning om hvordan innholdet ved YFL, er koherent til praksisfeltets organisering av innhold og arbeidsmåter på Vg1 for å få til tidlig yrkesspesialisering. Dermed er artikkelens problemstilling: Hvilke yrkesdidaktiske utfordringer og muligheter ses $i$ 
møtepunktet mellom YFL og studentenes pedagogiske praksis $i \mathrm{Vg} 1 \mathrm{DH}$, for å få til tidlig yrkesspesialisering?

Vi redegjør først for tidligere forskning knyttet til problemstillingen, før den didaktiske opplæringen på Vg1 DH og YFL blir belyst i et pragmatisk kunnskapsperspektiv. Resultatene presenteres og drøftes, før oppsummering med implikasjoner gis.

\section{Tidligere forskning på feltet}

En stor internasjonal studie viser viktigheten av nær koherens mellom praksisfeltet og lærerutdanningsinstitusjonens innhold (Canrinus mfl., 2017). Lærerutdanninger i fem land gjorde eksplisitte forsøk med å knytte teori og praksis sammen. Forsøkene handlet om koherens mellom teori og praksis på utdanningsinstitusjonen, og mellom undervisningen på utdanningsinstitusjonen og pedagogisk praksis i skolen. Forskningen synliggjør behov for bedre koherens mellom utdanningen og praksisfeltet (Canrinus mfl., 2017). Samtidig viser annen forskning at lite profesjonsretting og svak koherens mellom yrkes- og profesjonsutdanninger og praksisfeltet, er en utfordring i dagens lærerutdanninger i Norge (Heggen \& Terum, 2013; Hiim, 2015; Sylte 2018; Terum \& Smeby, 2014). Syltes (2017) forskning om didaktiske prinsipper for relevant yrkes- og profesjonsutdanning viser at koherens ikke bare er nødvendig mellom teori og praksis, men også mellom de ulike fagene i utdanningen, og mellom utdanningsinstitusjonen og arbeidslivet. Kjernen i prinsippene er analyse av yrkesoppgaver og -utøvelse som utgangspunkt for læreplananalyse og undervisningsplanlegging knyttet til helhetlig yrkeskompetanse. Young (2004) fremhever i sin forskning viktigheten av at fagarbeidere får innsikt i teoretiske nyvinninger som ligger til grunn for utviklingen av moderne yrke. Dette krever yrkesteoretisk innsikt knyttet til begrunnelser, kritikk og utvikling av yrkesutøvelsen. Uten slik innsikt vil yrkesutøvelsen og samfunnet mangle muligheter for faglig utvikling og fornyelse. En fare er hvis det kun er arbeidslivet som bestemmer hvordan utdanningene skal være. Det kan ende opp med sterk instrumentelt fokus på inntjening og å følge lærerens instruks i utdanningene. En konsekvens av dette kan være teorifattige og lite utviklende yrkes- og profesjonsutdanninger (Young, 2004). I rapporten; Nasjonal strategi for kvalitet og samarbeid i lærerutdanningene - Lærerutdanningene 2025 (KD, 2017), framheves behovet for samarbeid mellom skoler og lærerutdanninger, og mellom fag, fagdidaktikk, pedagogikk og praksis. Yrkesdidaktikk er ikke nevnt, noe som kan være tilfeldig, men som også kan skyldes at dette er et felt det er satt lite fokus på i både den utdanningspolitiske debatten og i utdanningsforskning generelt.

Tidligere forskning og evaluering av Kunnskapsløftet peker på at det er ulike tolkninger av læreplanene i utdanningsprogrammene, og hva som gir relevant yrkesopplæring (Bjørnstad, Ludvigsen \& Arnseth, 2013; Dahlback, Haaland \& 
Vagle, 2016; Hiim, 2013; Vibe mfl., 2012). Studier viser at mange skoleeiere, skoleledere og lærere tolker læreplanene slik at elevene det første året i videregående opplæring skal ha introduksjon i flere yrker. Mange elever blir pålagt en «smakebitpedagogikk» hvor de blir introdusert for mange ulike yrker i moduler gjennom hele skoleåret, selv om de i utgangspunktet hadde klare yrkesønsker da de startet på Vg1 (Dahlback, Hansen, Haaland \& Sylte, 2011; Hansen, 2017). Andre elever, spesielt innenfor Helse- og oppvekstfag, blir tilbudt et generelt teoretisk innhold på Vg1, som skal gi grunnlag for to år med praktisk yrkesopplæring i bedrift (Aarkrog \& Bang, 2013; Hansen, 2017). Forskning viser at måten de yrkesfaglige utdanningsprogrammene er organisert på, har praktisk betydning for om dagens yrkesfagelever får begynne på en spesifikk yrkesutdanning det første året eller ikke (Aarkrog \& Bang, 2013; Bødtker-Lund, Hansen, Haaland \& Vagle, 2017).

Både internasjonal og nasjonal forskning framhever behovet for å tydeliggjøre yrkes- og profesjonsutdanningenes yrkesrelevans der lærerne må styrke undervisningen og forankringen til arbeidslivet for å øke utdanningskvaliteten (Billett, 2014; Hiim, 2013; Jørgensen, Olsen \& Thunqvist, 2018). Sylte og Johanlus (2017) kvantitative forskning viser at studentene opplevde arbeidsmåter ved YFL relevante når de var knyttet til praksis, mens teoretisk undervisning uten sammenheng med praksis, opplevdes ikke relevant. Denne forskningen framhever viktigheten av profesjonsretting som koherens mellom skole og arbeidsliv. For YFL innebærer det at lærerutdanningens innhold og arbeidsmåter er koherent med studentenes pedagogiske praksis i skolen.

Annen nasjonal forskning peker på behov for å utvikle den pedagogiske praksisen i yrkesfaglærerutdanningene (Dahl, Bruland, Mordal \& Aaslid, 2012; Hansen \& Haaland 2015; Hiim, 2013; Landro \& Utvær, 2010). Bødtker-Lund mfl. (2017) framhever at lærerens kompetanse må utvides med kunnskap om yrkesog interessedifferensiering.

\section{Yrkesrelevant opplæring}

Kompetansemålene i Kunnskapsløftets læreplaner er åpne og generelle med stor grad av tolkningsrom for den enkelte lærer (KD, 2006). Forståelse av kompetanse handler om en form for helhetlig praktisk-teoretisk kunnskap i en yrkesfaglig kontekst. Helhetlig yrkeskompetanse innebærer at yrkesutøveren må vise evne til å utføre fagarbeid i et yrke og kunne løse sammensatte utfordringer knyttet til de enkelte arbeidsoppgaver eller til yrkesutøvelsen som helhet, samt forståelse og evne til refleksjon og kritisk tenkning (Sylte, 2017). Dette kompetansesynet er i tråd med Meld. St. 28 (2015-2016, s. 28) sin definisjon på kompetanse og et pragmatisk kunnskapssyn (Dewey, 1916; Hiim, 2013; Schön, 1987). Det betyr at innholdet i opplæringen er basert på en virkelighetsnær kontekstavhengig forståelse av praksisfeltet og ikke av abstrakte teorier eller fagdisipliner adskilt fra elevenes 
yrkesinteresser (Hiim, 2013). Helhetlig yrkeskompetanse omfatter også forståelse for hvordan yrket utøves, for dets funksjon i samfunnet, for dets kultur, tradisjon og utvikling (Sylte, 2017). Problemet er imidlertid at de generelle kompetansemålene fører til svært ulik tolkning, og dermed ulik praksis fra skole til skole, og fra lærer til lærer, slik våre studenter erfarte i sin pedagogiske praksis (Dahlback mfl., 2011).

Studentenes bakgrunn før opptak til YFL er fagbrev eller tilsvarende, og minimum fire års praksis i yrket. I løpet av studietiden opparbeider de yrkesfaglig dybdekompetanse gjennom praktisk arbeid, analyse av endrings- og kompetansebehov i eget yrke, og breddekunnskap om særtrekk og fellestrekk i de ulike yrkene som inngår i utdanningsprogrammet. Studentene har pedagogisk praksis med praksisveiledere, og yrkesfaglig praksis i arbeidslivet i løpet av studietiden. Dette er to viktige faktorer for å oppnå koherens mellom skole og arbeidsliv slik at lærerstudentene utvikler yrkesdidaktisk lærerkompetanse gjennom erfaring, refleksjon i og over veiledet praktisk erfaring i pedagogisk praksis i tråd med Deweys (1916), Billetts (2014), Ellströms (2012) og Schöns (1987) teorier. Målet med den veiledede pedagogiske praksisen er at studentene utvikler lærerkompetanse i yrkesdidaktiske undervisningsmetoder som kan bidra til at deres framtidige elever lærer å anvende praktisk-teoretisk kunnskap. Gjennom denne praktisk-teoretiske kunnskapen lærer studentene å skjelne mellom ulike situasjoner, som krever ulike yrkesdidaktiske handlinger i deres undervisningssituasjon. Dermed kan de vurdere situasjonen og handle mer intuitivt ut $i$ fra både teoretisk forståelse, og gjennom refleksjon i og over handling. Studentene opparbeider erfaring, og kan utvise klokskap og skjønn i ulike undervisningssituasjoner (Dewey, 1916; Schön, 1987).

Deweys (1895/1972) pragmatiske transaksjonsteoretiske læringsperspektiv innebærer eksperimentell læring hvor man ser på læring som måten levende organismer inklusiv mennesker, interaktivt tilpasser seg i sine miljøer. Det vil si en dynamisk samhandling med sine omgivelser der man må tilegne seg et komplekst og fleksibelt sett av vaner. Gjennom denne læreprosessen, vil for eksempel yrkesfagelevens eller YFL-studentens vaner, bli mer fokusert og mer spesifikt tilpasset skiftende forhold, og at læringen tilpasses de skiftende forhold som er realiteten for yrker. Deweys $(1916,2005)$ begrep erfaringslæring innebærer læring som en integrert del av aktiviteter innenfor et handlingsfelt, som for eksempel studentenes yrkesfaglige og pedagogiske praksis. Denne eksperimentelle måten å koordinere sine erfaringer med omgivelsene på, gir læring gjennom prøving og feiling. På den ene siden må eleven/studenten identifisere problemet, mens de på den andre siden må søke og utvikle forslag til løsninger: "Knowing is itself an activity, it is literally something which we do" (Dewey, 1916, s. 367). Betydningen av en koordinert handling som gir mening, vil si at man blir klar over noe ut fra det man giør og erfarer (Biesta, 2014). Det handler om at yrkesfageleven og YFLstudenten identifiserer problemer i yrkesutøvelsen og prøver ut og koordinerer 
handlinger som kan løse problemet, og som skaper forståelse og mening. Samtidig var det til dels store utfordringer i studentenes pedagogiske praksis, fordi skolene ved Vg1 DH organiserte opplæringen på ulike måter, som ikke opplevdes koherent med et slik pragmatisk profesjonsrettet læringsperspektiv som YFL vektlegger.

Profesjons- og yrkesrettet didaktisk opplæring er viktige mål både for YFL og yrkesfagopplæringen (HiOA, 2014; KD, 2006, 2013). Profesjonsretting av lærerutdanning defineres som: «Profesjonsperspektivet og nærhet til yrkesutøvelsen må vektlegges i arbeidet med kompetanseheving av alle faggrupper i lærerutdanningen» (St. meld. nr. 11, 2008-2009, s. 25). Både profesjons- og yrkesretting handler dermed om at opplæringen er basert på yrkesoppgaver og yrkesfunksjoner (Hiim, 2013; Sylte, 2016). Det innbefatter en yrkesdidaktisk tilnærming i tråd med Hiim og Hippes (2001) definisjon: "Praktisk-teoretisk planlegging, gjennomføring, vurdering og kritisk analyse av yrkesspesifikke utdannings- og læringsprosesser i skole og arbeidsliv" (s. 19). Deweys (1895/1972) transaksjonsteori innebærer et pragmatisk helhetsperspektiv der det vektlegges koordinering eller sammenheng mellom kunnskap og læreplaner. Men sammenhengen er ikke bare viktig i forhold til læreplanmålene og kunnskapsinnholdet i yrkes- og profesjonsdidaktikken. Den er også viktig knyttet til de øvrige didaktiske kategoriene arbeidsmåter/læreprosess, vurdering, læreforutsetning og rammefaktor (Hiim \& Hippe, 2001).

Hansen (2017) argumenterer for at også den enkelte elevs læringsbehov, som her også innbefatter elevenes utdannings- og yrkesvalg, bør styrkes i yrkesdidaktikkbegrepet. På Vg1 DH innebærer det yrkesrelevans gjennom yrkesretting og yrkesdifferensiering av opplæringen fordi utdanningsprogrammet rekrutterer til mange ulike yrker (Sund, 2005). Yrkesdifferensiering handler også om yrkesfaglærerens innsikt i de ulike yrkenes fellestrekk og særtrekk. En slik yrkesdidaktisk differensiert arbeidsmåte innebærer åpne oppgaver hvor elevene arbeider differensiert mot sine valgte yrker eller yrkesinteresser. Fellestrekkene læres gjennom felles erfaringslæring (Sund, 2005). Yrkesdifferensiering innebærer et pragmatisk kunnskapssyn (Dewey, 1916; Schön, 1987; Sund, 2005). Dewey (1916) var også opptatt av viktigheten elevens interesse har for læring. "Når det er nødvendigt at gøre undervisningsmaterialet interessant, er det tegn på, at det mangler forbindelse med endemålet og de tilstedeværende evner, eller også eksisterer der en forbindelse, men den opfattes ikke" (Dewey, 2005, s. 146). Dewey så elevens motivasjon for det som skal læres i sammenheng med interesse og målet for hva som skal læres. Det indikerer at opplæringene i Vg1 DH må organiseres slik at elever har mulighet til egendefinerte mål rettet mot sin yrkesinteresse. Det fordrer at YFL-studentene lærer yrkesdidaktisk innhold og arbeidsmåter hvor de kan legge til rette for yrkesdifferensiert opplæring i videregående skole og at opplæringen tar utgangspunkt i yrkesoppgaven og -utøvelsen som elevene er interessert i 
(Hiim, 2013). Med utgangspunkt i Deweys (1895/1972) pragmatiske transaksjonsteori, må innholdet og arbeidsmåtene praksislærerne bruker i sin undervisning koordineres til elevenes yrkesinteresser og mål med yrkesutdannelsen de velger.

I Reform-94 bestod utdanningen av fagene tegning, form, farge, kunst- og kulturhistorie, som krevde en fagdidaktisk tilnærming. Denne utdanningen innebar en mer generell opplæring i estetiske fag. Her ser vi et mer konvensjonelt didaktisk kunnskapssyn hvor disiplininndelt opplæring med fokus på fag og estetikk stod sentralt (Hiim, 2013). I fagdidaktikken står med andre ord skole- og vitenskapsfaget i sentrum (Sjøberg, 2001). Fagdidaktikk er dermed overveielser som er knyttet til et konkret skolefags situasjon i skole og utdanning (Hansen, 2017). Det innebærer et skille mellom teori og praksis - mellom yrkesopplæringen og yrket (Hiim, 2015; Schön, 1987).

I Kunnskapsløftet 2006 ble denne utdanningen strukturert i en estetisk kunstfaglig studiespesialiserende retning, og en DH-yrkesfaglig retning. DH skulle ivareta opplæringen av håndverksyrkene gjennom en yrkesdidaktisk tilnærming med fokus på arbeidsoppgaver og -prosesser forankret i yrkesutøvelsen (Hiim, 2013). Derfor var det interessant å undersøke om studentenes utfordringer også kunne ha sammenheng med praksislærernes praktisering av yrkes- eller fagdidaktikk.

\section{Metode}

Forskningen ble gjennomført i fire vårsemestre (2015-2018), og har en hermeneutisk fenomenologisk tilnærming (Gadamer, 2003; Patton, 2015). Hermeneutisk fenomenologisk forskning handler blant annet om å finne meningen og essensen i en opplevd erfaring (Gadamer, 2003; Kvale \& Brinkmann, 2009; Postholm, 2005). $\mathrm{Vi}$ var fire forskere som alle underviste ved YFL, og observerte studentene i deres pedagogiske praksis.

På bakgrunn av studentenes utfordringer i pedagogisk praksis, gjennomførte vi en digital kvalitativ spørreundersøkelse med 72 studenter, og dialogmøter med de samme studentene i etterkant av pedagogisk praksis (Patton, 2015). Videre gjennomførte vi semistrukturerte intervjuer med 15 tilfeldig utvalgte studenter og 15 praksislærere fra 13 videregående skoler i 10 ulike fylker (Kvale \& Brinkmann, 2009). Undersøkelsene handlet om å få en dypere forståelse om hvordan praksislærerne organiserte undervisningen ved Vg1 DH, og hvordan studentene opplevde sin pedagogiske praksis med bakgrunn i opplæringen de hadde fått ved YFL, der mål om tidlig yrkesspesialisering har vært fokusert.

\section{Analyse, validitet og etikk}

Dataene ble transkribert og sammenfattet ut fra Kvale og Brinkmanns (2009) tre nivåer; selvforståelse, kritisk forståelse basert på sunn fornuft og analysenivået 
med pragmatisk teoretisk forståelse. For å unngå å være suveren i utvelgelsen av empiriske eksempler, fikk informantene korrekturlese transkripsjonen av intervjuene og korrigere vår tolkning. Et moment som kan ha påvirket validiteten er at studentenes svar var basert på deres pedagogiske praksisperiode, mens lærerne svarte på bakgrunn av hele skoleåret. Dette var vi bevisste på i analysen og drøftingen av resultatene.

Vi brukte Excel og HyperResearch som analyseverktøy. Analysen tok primært utgangspunkt i prosjektets pragmatiske og yrkesdidaktiske teoretiske perspektiv. Kategoriene ble yrkesorientering, fagdidaktisk, yrkesdidaktisk, interessegruppering og samarbeid skole og arbeidsliv. Underkategoriene som fremkom ble muligheter og utfordringer knyttet til tidlig yrkesspesialisering.

Dataene er behandlet i tråd med etiske forskningsprinsipper, hvor prosjektet er registrert som nummer 56259 i Norsk senter for forskningsdata.

\section{Muligheter og utfordringer i studentenes pedagogiske praksis}

Gjennom analysen utpekte det seg i hovedsak fem ulike didaktiske tilnærminger, som praksislærerne organiserte opplæringen på: a) yrkesorientering, b) fagdidaktisk, c) yrkesdidaktisk, d) interessegruppering, og e) samarbeid skole- arbeidsliv. Alle viste både muligheter og utfordringer knyttet til yrkesrelevant opplæring og tidlig yrkesspesialisering på Vg1 DH. Faktorer som viste seg sentrale for praksislærernes valg av didaktiske tilnærminger, var blant annet tilgang på verksteder og lærerens kompetansebakgrunn. Litt over halvparten av praksislærerne hadde yrkesfaglig håndverksbakgrunn, mens resten hadde kunstfaglig- eller designbakgrunn.

\section{Yrkesretting gjennom yrkesorientering}

Ved noen praksisskoler yrkesorienterte lærerne elevene gjennom "smakebitspedagogikk", en periodevis orientering av utvalgte yrker som uten unntak var rettet mot skolens Vg2 tilbud. En praksislærer sa: "hos oss må alle elevene innom våre fire faste moduler (...)". Elevene fikk ingen mulighet til fordypning og lærte om ulike yrker som nødvendigvis ikke var relevante for videre utdanningsvalg.

Mange av praksislærerne sa de hadde yrkesrettet undervisningen. Ved oppfølgingsspørsmål om hva de la i yrkesretting, svarte flere at de orienterte om ulike yrker i løpet av skoleåret. Yrkesorientering har til hensikt å gi elevene innsikt i et utvalg av, eller flest mulig av yrkene som inngår i utdanningsprogrammet (Dahlback mfl., 2011). Flere praksislærere sa de synes det var en utfordring å finne en balanse mellom det å orientere om yrkene som inngår i utdanningsprogrammet med 52 ulike yrkesvalg, kontra det å gi utdanningen et yrkesrelevant innhold. En praksislærer sa: "(...) det går bort alt for mye tid til å orientere om ulike yrker på bekostning av å lære i dybden". 
Flere studenter erfarte elever med liten kunnskap om hvilke utdanningsmuligheter de hadde, og undret seg over hvorfor praksislærerne ikke hadde orientert om alle yrkesfagene i utdanningsløpet. En student sa: "Elevene var ikke klar over hvor mange yrkesfag det finnes innenfor DH (...)" (2016: student 5). Studentene etterspurte også praksislærernes kartlegging av elevenes yrkesinteresser: "Læreren visste ikke hva slags yrkesplaner elevene i klassen hadde, og de fikk ikke velge oppgaver opp mot sine yrkesinteresser (...)" (2017: student 7).

En av skolene hadde yrkesstasjoner der alle elevene var fem uker på hver stasjon. Student 8 (2017) skrev: " (...) elever som var sikre på at de ønsket trearbeid på Vg2, måtte jobbe på stasjonene for frisør, interiør- og utstillingsdesign, tekstil og metall $(. . .)^{\prime \prime}$. Praksislærere sa at elevundersøkelser viste at de fleste elevene var fornøyde med å jobbe med praktiske oppgaver, og at mange elever ombestemte seg etter å ha prøvd andre yrker enn det de i utgangspunktet hadde bestemt seg for.

Funnene viste at studentene erfarte utfordringer med den didaktiske organiseringen av opplæringen med faste yrkesstasjoner og yrkesorientering. Studentene opplevde her manglende koherens mellom innholdet i YFL og praksisskolen, fordi de ikke fikk anvende teorien om yrkesdifferensiert opplæring i tråd med Hiims (2013) forskning. Studentene etterspurte relevant undervisning for elever som hadde valgt et yrkesfag. Deres erfaringer var i tråd med BødtkerLunds mfl. (2017) forskning som viste at $60 \%$ av elevene hadde bestemt seg for et yrke når de begynte på Vg1. En student sa: "jeg forstår hvorfor mange elever slutter når opplæringen de får ikke gir mening" (2017, Student 7).

\section{Fagdidaktisk tilnærming, med gitte oppgaver uten mulighet for individuelle yrkesvalg}

Resultatene synliggjorde at flere skoler fremdeles gjennomførte undervisningen med fagdidaktisk tilnærming, slik praksis var i Reform-94. I intervjuet fortalte både praksislærere og studenter at de jobbet med gitte generelle oppgaver som var rettet mot form, farge, komposisjon og teknikker, som kun var relevante for noen yrkesfag. Dette til tross for at læreplanene i Kunnskapsløftet 2006 gir klare føringer om at utdanningen skal rettes mot aktuell og framtidig yrkesutøvelse. En praksislærer sa: "hos oss har vi fokus på felleselementene i opplæringen, det blir mest oppgaver rettet mot tegning, form og farge (...)". Studenter sa: " (...) elevene fikk kun generell undervisning, innføring og mulighet til å jobbe med gitte teknikker" (2016: student 11), og "Lite rom for at elevene selv fikk velge hva de ville jobbe med (...)" (2017: student 3).

Studentene fortalte om undervisning der alle elevene jobbet med den samme arbeidsoppgaven, som for eksempel å tegne logoer, lage lamper, vesker og masker. De opplevde at undervisningen ble gjennomført uavhengig av elevenes yrkesvalg. En student fortalte at alle elevene måtte lære å sy knapphull, selv om ingen av elevene hadde valgt Vg2 Design og tekstil som videre utdanningsløp. 
Praksislæreren hadde fagbakgrunn fra kjole- og draktsyerfaget, og mente at det å sy knapphull var en grunnleggende kompetanse for alle elevene. En annen student fortalte at elevene egentlig skulle jobbe med å lage masker, selv om mange elever hadde søkt videre til frisørfaget: "Jeg fikk likevel lov til å yrkesrette opplæringen mot frisørfaget i noen av timene (...). Vg2 elever som fikk se hva vi jobbet med sa: " (...) så heldige dere er som får jobbe mot frisørfaget allerede på Vg1 (...)" (2017: student 5).

En student med frisørbakgrunn fortalte at hun underviste på verksteder i tekstil, keramikk og trearbeid, selv om de fleste elevene hadde frisør som sitt førstevalg på Vg2. Hun spurte praksislærer om å få yrkesrette undervisningen mot frisørfaget. Praksislæreren mente imidlertid at elevene skulle lære ulike teknikker på Vg1, og sa at frisørfaget kunne elevene lære i yrkesfaglig fordypning (YFF) og på Vg2.

Funnene viser at det generelle faglige innholdet ikke ble yrkesrettet i tråd med Kunnskapsløftets intensjoner, og at undervisningen var innføring i kontekstfri teori, der temaene var generelle med lav yrkesrelevans. Den fagdidaktiske tilnærmingen var forankret $i$ et konvensjonelt kunnskapssyn i stedet for et pragmatisk yrkesdidaktisk (Hiim, 2013). En student som etterlyste yrkesforankring og differensiering i sin praksisperiode sa: "En blomsterdekoratør bruker tegning og farge forskjellig fra en frisør, og trenger en annen type kunnskap og ferdighet enn det de fikk opplæring i for å kunne utøve sitt yrke" (2016: student 14).

Resultatene peker på at studentene som var på praksisskoler med fagdidaktisk tilnærming i liten grad fikk prøvd ut yrkesdifferensiert undervisning i tråd med Deweys (2005) teori om viktigheten av elevers interesse og egendefinerte mål for læring. Studenter fortalte at de følte seg usikre i undervisningen, og mange opplevde manglende kompetanse i generell tegning, form og farge. Flere etterlyste denne kompetansen ved YFL utdanningen, men var likevel klare på at opplæringen måtte yrkesrettes, for å få en yrkesrelevant opplæring med tidlig yrkesspesialisering. Samtidig peker tidligere forskning på sammenhengen mellom lærerens fagbakgrunn og kunnskapssyn, og lav yrkesrelevans gjennom manglende hensyn til elevers yrkesinteresse og egendefinerte mål i brede utdanningsprogram (Bødtker-Lund mfl., 2017).

\section{Yrkesdidaktisk tilnærming med yrkesdifferensiering}

Noen av skolene var preget av et pragmatisk kunnskapssyn og en yrkesdidaktisk tilnærming i tråd med Sunds (2005) modell for yrkesdifferensiert opplæring (Nielsen \& Haaland, 2013). Modellen tar utgangspunkt i elevenes yrkesinteresser og videre utdanningsplaner i tråd med Deweys $(1916,2005)$ tenkning, samt yrkesoppgaven og yrkesutøvelsen som grunnlag for kontekstuell opplæring i brede utdanningsprogram (Hiim, 2013).

I intervjuet svarte alle praksislærerne at de yrkesdifferensierte undervisningen. En praksislærer sa: "Vi lar elevene velge hvilket yrke de ønsker å rette 
oppgavene sine mot". Studentenes fortalte derimot at få praksislærerne gjennomførte yrkesdidaktisk tilnærming i løpet av praksisperioden. Funnene viser at mange både lærere og studenter hadde store utfordringer i forhold til rammene når de skulle gjennomføre yrkesdidaktisk tilnærming i praksis. En praksislærer sa: "Jeg har verken kompetanse eller utstyr til å gi interessedifferensiert opplæring til elevene i min klasse". Flere lærere fortalte om mangel på materialer, verktøy, verksteder, utfordrende samarbeid med næringslivet og mangel på kompetanse i yrkenes særtrekk og fellestrekk. Studenter mente i likhet med Nielsen og Haaland (2013) at utfordringene også kunne knyttes til manglende kompetanse i å lede læringsprosesser med felles læringsmål og ulike oppgaver og materialer.

Flere studenter fortalte at de ikke fikk jobbe med yrkesdifferensierte elevoppgaver, andre ble direkte frarådet å jobbe på denne måten. En student sa: "praksislærer sa det ikke fungerte å yrkesrette oppgavene, og frarådet meg å lage åpne oppgaver" (2017: student 5). Studentene undret seg over at elevenes yrkesinteresser ikke skulle påvirke undervisningen når elevene allerede hadde søkt på Vg2. Flere studenter fortale om endringer i elevenes motivasjon for elevarbeid når elevoppgavene ble yrkesdifferensierte. En praksisveileder sa: "Oppgavene var opprinnelig styrt av meg mot interiør. Studenten foreslo yrkesretting mot ulike yrker, noe som ble godt mottatt av elevene". I denne klassen var det kun to elever som hadde valgt interiør som sitt videre løp på Vg2.

Studien synliggjør at studentenes opplevelse av relevans og mening mellom teorien på YFL og pedagogisk praksis er knyttet til i hvilken grad studentene fikk gjennomføre yrkesrelevant undervisning med tidlig yrkesspesialisering. Vi ser også at studentene som fikk lede læringsprosesser og yrkesdifferensiere undervingen ønsket å videreutvikle sin yrkesdidaktiske kompetanse i studiet.

\section{Interessegrupper rettet mot de vg2 løpene skolen tilbyr}

Ved andre skoler som var preget av et pragmatisk kunnskapssyn og yrkesdidaktisk tilnærming, fortalte både praksislærerne og studentene at skolene hadde etablerte interessegrupper rettet mot skolens Vg2 løp. Praksislærerne begrunnet dette med skolens verksteder, lærernes kompetanse og at det var i disse yrkesfagområdene de kunne gi yrkesrelevant undervisning. Hvis elevene ønsket å bli frisører, fikk de opplæring mot frisørfaget i både felles programfag (PF) og i YFF gjennom hele skoleåret. En praksislærer sa: "Hos oss har vi interessegrupper i frisør og interiør, resten av elevene er samlet i en felles klasse (...)". På denne skolen var det flest elever som ønsket å utdanne seg til frisører og interiørkonsulenter, og mange av de som var i klassen med andre yrkesinteresser var usikre på videre valg.

Praksislærere og studenter fortalte om interessegrupper som fungerte godt for de elevene som ønsket å bli frisør, men flere så utfordringene når elever oppdaget at de hadde valgt feil. En praksislærer sa: "jeg hadde en elev som langt ut i skoleåret ombestemte seg, og ønsket å bli blomsterdekoratør istedenfor frisør (...)". 
En annen praksislærer uttrykte også bekymring og sa: "Det blir veldig stor forskjell på de elevene som har hatt tidlig fordypning, og de som ikke har fått prøve sitt yrke i løpet av skoleåret i det hele tatt". Andre praksislærere mente dette var forsvarlig, da alle elevene nådde kompetansemålene for Vg1. En praksislærer som også jobbet på Vg2 Design og tekstil sa: "Vi er vant til at elevene har ulik kompetanse når de kommer til oss, da vi får elever fra forskjellige skoler".

I ett fylke fortale lærerne at de samarbeidet på tre skoler og hadde interessegrupper på tvers av skolene. Tilbudet var tilpasset skolenes verksteder og lærerkompetanse. Samlet kunne de tilby elevene opplæring innen frisør-, interiør- og utstillingsdesigns-, blomsterdekoratør-, tekstil-, metall- og trearbeiderfag. En praksislærer sa: "Dette har fungert veldig bra, og vi har planlagt å fortsette forsøket også til neste år". Både studenter og praksislærere opplevde imidlertid utfordringer når for eksempel elever måtte fortsette i opprinnelig interessegruppe selv etter at de hadde endret yrkesvalg.

Studentene fortalte at de på disse skolene fikk undervise i interessegrupper knyttet til egen yrkesfagbakgrunn. De opplevde at undervisningen fungerte godt, og begrunnet det med at de underviste i et yrkesfag de hadde god innsikt. En student sa imidlertid: "litt synd jeg ikke fikk erfaring i å jobbe med bredden på Vg1" (2018: student 4). Flere som denne studenten savnet erfaring $\mathrm{i}$ å undervise elever med ulike utdanningsplaner i sin praksis ved Vg1, og opplevde at disse skolenes tilnærming gjorde at de ikke fikk prøvd ut opplæringen de hadde fått på YFL i praksis. Dette til tross for at undervisningen innfridde krav om tidligere fordypning (Meld. St. 28, 2015-2016).

\section{Samarbeid skole og arbeidsliv}

Kunnskapsløftet 2006 gir føringer om et forpliktende samarbeid mellom skole og arbeidsliv på alle nivåer i opplæringen (NOU 2008:18, s. 31). Selv om dette har vært prioritet fra nasjonalt hold (Buland \& Fonn, 2010; Meld. St. 20, 2012-2013; Nyen \& Hagen, 2012), viser Nyen og Tønder (2012) til utfordringer med manglende etablert samarbeid mellom skole og arbeidsliv. I 2016 ble faget Prosjekt til fordypning erstattet med Yrkesfaglig fordypning (YFF). Formålet med YFF var blant annet å gi elevene en styrket mulighet til prøve ut ett eller flere aktuelle lærefag, som grunnlag for valg av yrke (Udir, 2016).

Til tross for nye føringer peker resultatene i denne studien på at det fremdeles var opp til hver enkelt praksislærers nettverk og skolens rammer, i hvilken grad samarbeidet med arbeidslivet fungerte. Alle praksislærere sa at nettverksbygging og samarbeidet med arbeidslivet var en viktig faktor for relevant yrkesopplæring. Allikevel fortalte de at bare under halvparten av elevene hadde yrkespraksis i arbeidslivet i løpet av Vg1. Mange av praksislærerne sa de manglet tid til å vedlikeholde og etablere nye kontakter med arbeidslivet, flere etterlyste egne midler til en eller flere praksiskoordinatorer. En praksislærer sier: "jeg har ikke tid til å skaffe praksisplasser, hadde vært til stor hjelp om ledelsen hadde lagt 
bedre til rette $(. . .)^{\prime \prime}$. Flere praksislærere poengterte nødvendigheten av at skolelederne måtte gi bedre rammer for et samarbeid mellom skole og arbeidsliv, slik at praksislærerne kunne prioritere dette.

Noen praksislærere poengterte at de valgte å spare praksisplassene til Vg2 elevene, fordi Vg1 elevene kunne for lite til å ha praksis i arbeidslivet, og mange ikke visste hva de ønsket å utdanne seg til. De fortale imidlertid at de var positive til å ha elevene ut i praksis når elevene hadde klare yrkesplaner og skolen ikke kunne tilby opplæring innen fagområdet. Mange studenter sa derimot at: "(...) elevene kunne velge å være på skolen å skrive om et fag, istedenfor å være ute i praksis" (2016: student 4). Mange studenter henviste også til at mye av praksisen som ble gjennomført i arbeidslivet ikke var rettet mot yrkene som var relevante for $\mathrm{DH}$. "Det virket som om de kunne velge nesten hva som helst, mange jobbet i klesbutikker eller parfymerier" (2015: student 6).

Elevene fikk ifølge andre praksislæreres utsagn kun jobbe med det yrket de ønsket å utdanne seg til når de hadde YFF i arbeidslivet. En praksislærer sa: "Jeg klarer ikke å yrkesrette undervisningen mot alle fag, men de får jobbe mot sitt yrkesvalg når de er ute i bedrift (YFF)". Flere poengterte også at det var først når eleven kom ut i praksis at de så hva yrket handlet om. Mange elever oppdaget feilvalg, mens andre ble styrket $i$ at de hadde valgt riktig. Et betimelig spørsmål i henhold til våre funn kan da være om relevant praksis i arbeidslivet vil kunne bidra til å redusere frafall i videregående opplæring. Hiims (2013) forskning synliggjør at mange elever gjør feilvalg og mange trenger å erfare ulike yrker før de gjør bevisste yrkesvalg.

En tredjedel av praksislærerne sa de brukte fagfolk fra arbeidslivet $\mathrm{i}$ undervisningen, og som dialogpartnere for å sikre yrkesrelevans i opplæringen. En praksislærer sa: "på vår skole er det kun meg med yrkesfagligbakgrunn, så jeg er helt nødt til å bruke gjestelærere fra arbeidslivet (..)". Ellströms (2012) forskning poengterer i likhet med disse praksislærerne, viktigheten av å kjenne arbeidslivet fra innsiden, og å samarbeide om hvordan man sikrer kvalitet gjennom reflekterende dialoger. Studentene fortalte at den nettverksbyggingen de hadde gjort $\mathrm{i}$ løpet av studiet var meget viktig og en student fortale: "Yrkespraksis har gitt meg betydelig innsikt i ulike yrker, og et unikt nettverk som jeg senere kan bruke som yrkesfaglærer" (2016: student 13). Billett (2014) poengterer også behovet for å tydeliggjøre profesjonsutdanningenes yrkesrelevans, der lærerne må styrke undervisningen og forankringen til arbeidslivet for å øke lærerutdanningskvaliteten. Likedan peker Sylte og Johanlus (2017) forskning i likhet med Aarkrog og Bangs (2012) forskning, på viktigheten av å styrke samarbeidet mellom skoler og bedrifter i yrkesfaglærerutdanningen: "Kompetanseutvikling av lærerens ferdigheter bør inneholde en oppdatert forståelse av praksis i bedrifter" (Aarkrog \& Bang, 2012, s. 22).

Våre funn viser at praksis i arbeidslivet fremdeles må være en del av opplæringen for studentene ved YFL, slik at de får opparbeidet innsikt i yrkene som 
inngår i Vg1 DH. Imidlertid er det ikke mulig og heller ikke hensikten at studentene skal kunne utøve alle de 52 ulike yrkene som inngår i utdanningsprogrammet. Vi ser derimot nødvendigheten av å bygge opp et nettverk av dyktige fagfolk og bedrifter som studentene kan samarbeide med som kompetente yrkesfaglærere i Vg1. Dette kan ses i tråd med Deweys (1895/1972) pragmatiske transaksjonsteori hvor helhetsperspektivet vektlegges. I den sammenheng peker også Sylte $(2017,2018)$ sin forskning på et viktig didaktisk prinsipp for relevant yrkesog profesjonsutdanning. Det innebærer nødvendigheten av koherens mellom både teori og praksis, de ulike fagene i utdanningen og mellom utdanningsinstitusjonen og arbeidslivet. Dermed vil det for yrkesfagelevene også være viktig å ha praksis $\mathrm{i}$ arbeidslivet for å lære og å forstå.

En av utfordringene er at mange av virksomhetene innen DH er små bedrifter med kun en til tre ansatte, der det er vanskelig for mange å finne tid og økonomi til å veilede elever og studenter. Dette gjør at mange ikke tar imot elever eller studenter i praksis. En utfordring er derfor hvordan vi kan motivere flere, også av de små bedriftene, til å se en vinn-vinn-situasjon ved å ha praksiselever og studenter i praksis. Uten samarbeid med arbeidslivet vil det $\mathrm{i}$ henhold til våre funn være en nesten umulighet å tilby tidlig yrkesspesialisering til alle yrker.

\section{Didaktiske utfordringer og muligheter i møtepunktet mellom YFL og studentenes pedagogiske praksis}

Resultatene peker på til dels store utfordringer knyttet til undervisningen ved Vg1 DH. Den største utfordringen lå i manglende yrkesrelevant innhold i opplæringen. Formålet i læreplanen for utdanningsprogrammet DH (Udir, 2006) sier at opplæringen skal bidra til utvikling av håndverksmessige ferdigheter og grunnleggende yrkeskompetanse. Resultatene viser imidlertid at innholdet opplevdes lite relevant når praksislærere underviste kun med utgangspunkt i sitt eget yrke, uten å gi eksempler til de yrkene elevene konkret ønsket å utdanne seg til. Manglende medvirkning, og at alle måtte løse de samme oppgavene uavhengig av egne utdanningsplaner var, ifølge studentene, demotiverende for mange av elevene. Ut fra Deweys (2005) pragmatiske teori om viktigheten av elevers interesse for å lære, kan dette forklare noe av elevenes reaksjoner. En slik gjeldende praksis er, slik vi vurderer det dessuten i strid med politiske føringer om å styrke yrkesspesialiseringen på Vg1 (Meld. St. 28 2015-2016).

Ut fra utdanningenes formål og et pragmatisk kunnskapsteoretisk perspektiv, ser vi det nødvendig at opplæring tar utgangspunkt i elevenes yrkesinteresse, og at den må ses i sammenheng med yrkesoppgaven og yrkesutøvelsen (Dewey, 1916; Hiim, 2013). Selv om Dewey (1916) påpeker viktigheten av elevers interesse knyttet til læring, vektla flere av lærerne en fagdidaktisk tilnærming på bekostning av elevenes yrkesinteresse. Dreyfus og Dreyfus (1986) mener elever på novisenivå trenger regler og eksempler for handling, men det betyr ikke at for ek- 
sempel tegning skal læres atskilt fra yrkespraksisen. Resultatene bekrefter tidligere forskning om at mangel på yrkesrelevant opplæring knyttet til hver enkelt elevs videre utdanningsplaner, fortsatt er et av hovedproblemene i dagens skole (Aspøy mfl., 2017; Bødtker-Lund mfl. 2017; Hansen, 2017). Dermed kan resultatene med mye fokus på fagdidaktisk versus yrkesdidaktisk tilnærming ved Vg1 DH, svekke kvaliteten i yrkesopplæringen.

En annen utfordring var at praksisen studentene møtte i skolen ikke var koherent med YFLs innhold. Funnene synliggjør at det er forskjeller i hva praksislærerne tolker er relevante arbeidsmåter og innhold, og på grunnlag av det, også hvilke kompetanser en kompetent yrkesfaglærer trenger. Mange av fagdidaktikerne mente studentene trengte mer generell kompetanse innenfor tegning, form og farge. En slik fagdidaktisk tilnærming i pedagogisk praksis, vil i tråd med Deweys (1916) pragmatiske perspektiv på læring, kunne hindre studentene i å velge yrkesdidaktiske tilnærminger ut fra elevenes yrkesvalg. Samtidig kan vi også se noe av fagdidaktikernes argumentasjon om at studentene også trenger denne kunnskapen. Utfordringen ligger imidlertid mer i at denne kunnskapen må yrkesrettes mot elevenes yrkesvalg hvis yrkesopplæringen skal imøtekomme fremtidens kompetansebehov og kravet om tidligere yrkesspesialisering (Udir, 2018). Yrkesdidaktikerne var jevnt over mer opptatt av at studentene kunne lede læringsprosesser, samt å yrkesrette opplæringen i tråd med Hiim (2013) og Sund (2005) sin forskning.

Studentene har solid fagkompetanse med seg fra sitt eget yrkesfag, og gjør mye god praksis uten alltid å være bevisst hvorfor de gjør det de gjør. Yrkesdidaktiske refleksjoner hjelper dem å se hva de gjør og hvorfor, for å bli en kompetent yrkesfaglærer. Dette sammen med kritiske analyser av hva som er relevant og for hvem, i tråd med Schöns (1987) reflection in action. Selv om studentene får mulighet til å reflektere over sin pedagogiske praksis gjennom veiledning og individuelle refleksjonsnotater, er det også nødvendig med koherens mellom teori og praksis. Både Dewey (1916) og Schön (1987) er også opptatt av at studenter utvikler klokskap og dømmekraft i handlingen, noe som er i tråd med Meld. St. 28 (2015-2016) sin definisjon av kompetanse. Den innebærer forståelse og evne til refleksjon og kritisk tenkning. Her vektlegges en mer helhetlig yrkeskompetanse som også handler om å anvende praktisk-teoretisk kunnskap til å mestre utfordringer og løse problemer i kjente og ukjente sammenhenger og situasjoner (Dewey, 1916; Schön, 1987; Sylte, 2017).

Studentene sa det var viktig for dem å få muligheten til å prøve ut yrkesdidaktiske opplegg i sin pedagogiske praksis, for å kunne opparbeide nødvendig kompetanse for å bli kompetente yrkesfaglærere. Dette lot seg ikke gjøre ved alle praksisskoler, noe som kan bety at YFL ideelt sett bør samarbeide med praksislærere som har en yrkesdidaktisk tilnærming til feltet. Konsekvensene av en fagdidaktisk tilnærming kan føre til at elevene ikke får tidlig yrkesspesialisering (Meld. St. 28, 2015-2016; Udir, 2018). Samtidig er det også viktig med koherens 
(Canrinus mfl., 2017; Heggen \& Terum, 2013; Terum \& Smeby, 2014), noe en fagdidaktisk tilnærming kan bidra til å svekke mellom YFL og Vg1 DH. Utfra våre funn ser vi manglende samsvar mellom hva studentene lærer ved YFL og gjeldende praksis ved Vg1 DH. Det var også til dels manglende koherens mellom Vg1 DH og arbeidslivets behov for kompetanse. Samtidig er det viktig at utdanninger ikke bare er på arbeidslivets premisser som for YFL er Vg1. Faren er at det kan føre til et sterkt instrumentelt fokus med disiplininndelt fagdidaktisk opplæring i stedet for yrkesdidaktisk. Det kan igjen lede til lite utviklende yrkes- og profesjonsutdanninger, der studentene eller elevene kun lærer smale felt i et yrke i stedet for helhetlig yrkeskompetanse (Young, 2004).

Et hovedanliggende er at elevene kan arbeide opp mot egne valgte yrker innenfor samme læringsmål (Nilsen \& Haaland, 2013). Et overordnet resultat viser at nettverksbygging kan bidra til dette og fremheves som særdeles viktig av både studenter og praksisveiledere, hvor en student sa: "Yrkespraksis har gitt meg betydelig innsikt i ulike yrker, og et unikt nettverk som jeg senere kan bruke som yrkesfaglærer". Et sentralt funn er at opplæringen bør foregå i samarbeid med kvalifiserte yrkesutøvere i skoler eller arbeidslivet innenfor de yrkene yrkesfaglæreren / studentene ikke selv har sin bakgrunn.

\section{Oppsummering og veien videre}

For å trekke fram noen hovedfunn, viser resultatene store yrkesdidaktiske utfordringer med til dels manglende koherens mellom YFLs innhold og studentenes praksisopplæring ved Vg1 DH. Hovedårsaken ser ut til å henge sammen med mange av praksislærernes organisering av innhold og arbeidsmåter i praksisperioden, og manglende nettverk og samarbeid med arbeidslivet. Konsekvensen av dette er at mange av våre studenter hverken får praktisert yrkesrettet eller yrkesdifferensiert undervisning i løpet av praksisperioden.

Et pragmatisk teoretisk perspektiv på læring og tidligere forskning påpeker nødvendigheten av koherens mellom skole og arbeidsliv. Nødvendigheten av koherens gjelder ikke bare mellom YFL og Vg1 DH, den er også like viktig mellom videregående skole og arbeidslivet. Ut fra vår forskning, teorigrunnlaget og tidligere forskning, ser vi nødvendigheten for en yrkesdidaktisk tilnærming i brede vg1. Det må legges til rette for tidligere yrkesspesialisering i skolen, noe våre funn synliggjør kan være vanskelig så lenge store deler av Vg1 DH fremdeles preges av en fagdidaktisk tilnærming.

Ut fra resultatene ligger de største mulighetene for å oppnå koherens mellom YFL og Vg1 DH, i organiseringen av opplæringen ved Vg1 DH. Denne organiseringen pekte også på til dels svak koherens til DHs arbeidsliv, ved at mange elever ikke hadde praksis i arbeidslivet i løpet av Vg1. Et av hovedfunnene viser nødvendigheten av tidligere yrkesspesialisering gjennom yrkesdifferensiert opplæring for de elevene som har et bevisst yrkesvalg. Dette er også i tråd med den 
nye tilbudsstrukturen (Udir, 2018). Tidligere yrkesspesifisering i videregående skole vil slik sett ikke gi de store implikasjonene for YFLs innhold, som heller ikke kan gå på akkord med didaktiske prinsipper for relevant yrkes- og profesjonsutdanning for å oppnå koherens (Sylte, 2017). I lys av Youngs (2004) argumentasjon vil det som sagt føre til mer teorifattige og lite utviklende yrkes- og profesjonsutdanninger. YFLs innhold bør imidlertid styrkes på kompetanse, som for eksempel tekniske ferdigheter, knyttet til de ulike yrkene som inngår i Vg1 DH. Samtidig vil en slik styrking gi mindre utfordringer i den nye utdanningsstrukturen, der den ene delen av DH får seks yrker mot dagens 52. Den andre delen av DH vil imidlertid fremdeles lede til 43 ulike håndverksfag (Udir, 2018). Dermed er det sannsynlig at YFL-studentenes fortsatt vil møte like store utfordringer i sin pedagogiske praksis, hvis ikke koherensen styrkes mellom YFL gjeldende praksis i Vg1 DH. Dermed ser vi i tråd med Dahl mfl. (2012), Hansen og Haaland (2015), Hiim (2013) og Landro og Utvær (2010), behovet for å utvikle den pedagogiske praksisen i yrkesfaglærerutdanningene. Våre funn viser at muligheter for studentene til å arbeide med tidlig yrkesspesialisering også må styrkes.

Selv om vi ikke kan generalisere på bakgrunn av vår forskning ved Vg1 DH, så er det i Norge flere yrkesfaglige Vg1-programmer som har felles bred opplæring for mange ulike yrker. Derfor er det stor sannsynlighet at de empiriske eksemplene på yrkesdidaktisk og yrkesdifferensiert tilnærming av opplæringen i Vg1 DH, vil være overførbar til andre Vg1 programområder. Implikasjonene for YFL og resultater fra forskningen vil brukes til å videreutvikle samarbeidet med Vg1-feltet med mål om tidligere yrkesspesialisering i tråd med fremtidens tilbudsstruktur (Udir, 2018). Dette peker på behov for etter- og videreutdannings tilbud tilpasset yrkesfaglærernes fremtidige kompetansebehov i yrkesdidaktikk og fordypning i yrkesfagene.

\section{Sluttnote}

${ }^{1}$ Jorunn Dahlback, Hanne Berg Olstad, Ann Lisa Sylte og Anne-Catrine Wolden, OsloMet - storbyuniversitetet, er likeverdige forfattere av denne artikkelen.

\section{Om forfatterne}

Jorunn Dahlback er førstelektor ved OsloMet - storbyuniversitetet, Fakultet for lærerutdanning og internasjonale studier. Hun har lang erfaring med undervisning og veiledning ved bachelorutdanningen yrkesfaglærer i design og håndverk, arbeidsplassbasert yrkesfaglærerutdanning og yrkesfaglærerløftet. Hennes forskningsinteresser er yrkesrelevant, kompetanse- og praksisbasert opplæring, 
vurdering og realkompetansevurdering. Hun har mange års erfaring med forskning innenfor fag- og yrkesopplæring, er opptatt av nettverksbygging og samarbeid universitet, skole og arbeidsliv.

Hanne Berg Olstad er universitetslektor ved OsloMet - storbyuniversitet, Fakultet for lærerutdanning og internasjonale studier. Hun underviser ved bachelorutdanningen yrkesfaglærer i design og håndverk. Hennes forskning og utviklingsarbeid er knyttet til samarbeid universitet, skole og arbeidsliv, med fokus på organisering og innhold i opplæringen.

Ann Lisa Sylte er førsteamanuensis ved OsloMet - storbyuniversitet, Fakultet for lærerutdanning og internasjonale studier. Hun har lang erfaring fra undervisning og veiledning ved universitets- og høgskolepedagogikk, yrkesfaglærerutdanning og master i yrkespedagogikk, samt forskningsarbeid og forskningsgruppeledelse. Hennes forskningsarbeid har fokus på relevant yrkes- og profesjonsutdanning som f.eks. didaktiske prinsipper for yrkes- og profesjonsretting av innhold, arbeidsmåter og vurdering, samt samarbeid universitet, skole og arbeidsliv.

Anne-Catrine Wolden er universitetslektor ved OsloMet - storbyuniversitet, Fakultet for lærerutdanning og internasjonale studier. Hun underviser ved bachelorutdanningen yrkesfaglærer i design og håndverk. Hennes forskning og utviklingsarbeid er knyttet til utvikling av relevant yrkesfaglærerutdanningen, samarbeid universitet, skole og arbeidsliv, profesjonsfaglige digitale kompetanse og videreutvikling av læringsaktiviteter innen yrkes- og profesjonsutdanning. 
Utfordringer og muligheter i møtepunktet mellom yrkesfaglærerutdanningen og praksis

\section{Referanser}

Aarkrog, V. \& Bang, S.W. (2013). Resultater af evalueringer af Kunnskapsløftet: En syntese. Aarhus: Aarhus Universitet.

Aspøy, T., Skinnarland S. \& Tønder, A.H. (2017). Yrkesfaglærerens kompetanse. Fafo-rapport 2017:11. Oslo: Fafo.

Biesta, G.J.J. (2014). Pragmatising the curriculum: Bringing knowledge back into the curriculum conversation, but via pragmatism. Curriculum Journal, 25(1), 29-49.

Billett, S. (2014). The standing of vocational education: Sources of its societal esteem and implications for its enactment. Journal of Vocational Education \& Training, 66(1), 1-21.

Bjørnestad, E., Ludvigsen, S. \& Arnseth, H.C. (2013). Kunnskapsløftet: Hva viser forskningen? Norsk Pedagogisk Tidsskrift, 97(6), 351-354.

Bødtker-Lund, D., Hansen, H.K., Haaland. G. \& Vagle, I. (2017). Hvordan fungerer Vg1 - yrkesfaglige utdanningsprogram for elever med ulike utdanningsplaner og yrkesvalg? Oslo: SJEVD.

Bueland, T. \& Fonn, K.H. (2010). Når ulike verdener møtes: sluttprosjekt for prosjekt vandreboka. SINTEF-rapport A15401. Trondheim: SINTEF.

Canrinus, E.T., Bergem, O.K., Klette, K. \& Hammerness, K. (2017). Coherent teacher education programmes: Taking a student perspective. Journal of Curriculum Studies, 49(3), 313-333.

Dahl, T., Bruland, S., Morland, S. \& Aaslid, B.E. (2012). På de samme stier som før: Kunnskapsløftet i fag- og yrkesopplæringen. Trondheim: SINTEF.

Dahlback, J., Hansen, K., Haaland, G. \& Sylte, A.L. (2011). Yrkesdidaktisk kunnskapsutvikling og implementering av nye læreplaner (KIP): Veien til yrkesrelevant opplaring fra første dag $i \mathrm{Vg1}$. Oslo: Høgskolen i Oslo og Akershus.

Dahlback, J, Haaland, G. \& Vagle, I. (2016). Arbeidsplassbasert treårig yrkesfaglærerutdanning (ABY). HiOA rapport 2016 nr. 1. Oslo: Høgskolen i Oslo og Akershus.

Dewey, J. (1916). Democracy and education. New York: Mc Millian.

Dewey, J. (2005). Demokrati og uddannelse. Århus: Forlaget Klim.

Dewey, J. (1972). Plan of organization of the university primary school. I J.A. Boydston (Red.), Early works: 1882-1898: Vol. 5. 1895-1898: Early essays (s. 96109). Carbondale: Southern Illinois University Press. (1. utgivelse 1895).

Dreyfus, H. \& Dreyfus, S. (1986). Mind over machine: The power of human intuition and expertice in the era of the computer. New York: Free press.

Ellström, P-E. (2012). Læring i spændingsfeltet mellem produktionens og udvilingens logic. I K. Illeris (Red.), 49 tekster om laring (s. 467-476). Fredriksberg: Samfunnslitteratur.

Gadamer, H-G. (2003). "2". Forståelsens filosofi. Oslo: Cappelen Akademisk Forlag. 
Hansen, K.H. (2017). Hva er yrkesdidaktikk i dagens yrkesopplæring i skole? Scandinavian Journal of Vocations in Development, 2.

Hansen, K.H. \& Haaland, G. (2015). Utfordringer i norsk yrkesopplæring. I K. Hansen, T.L. Hoel \& G. Haaland (Red.), Tett på yrkesopplæring (s. 19-46). Bergen: Fagbokforlaget.

Heggen, K., \& Terum, L.I. (2013). Coherence in professional education: Does it foster dedication and identification? Teaching in Higher Education, 18(6), 656669.

Hiim, H. (2013). Praksisbasert yrkesutdanning: Hvordan utvikle relevant yrkesutdanning for elever og arbeidsliv? Oslo: Gyldendal Akademisk.

Hiim, H. (2015). Kvalitet i yrkesutdanningen: Resultater fra et aksjonsforskningsprosjekt om yrkesforankring av innholdet i yrkesutdanningen. Norsk pedagogisk tidsskrift, 99(2), 136-148.

Hiim, H. \& Hippe, E. (2001). Å utdanne profesjonelle yrkesutøvere. Oslo: Gyldendal Akademisk.

Høgskolen i Oslo og Akershus (HiOA). (2014). Programplan Bachelorstudium: Yrkesfaglærerutdanning design og håndverk. Akershus: Høgskolen i Oslo og Akershus.

Jørgensen, H-J., Olsen, O.J. \& Thunquist, D.P. (2018). Vocational education in the nordic countries: Learning from diversity. London \& New York: Routledge.

Kunnskapsdepartementet. (2006). Læreplanverket Kunnskapsløftet. Oslo: Kunnskapsdepartementet.

Kunnskapsdepartementet. (2013). Forskrift om rammeplan for yrkesfaglærerutdanning for trinn 8-13. Oslo: Kunnskapsdepartementet.

Kunnskapsdepartementet. (2017). Lærerutdanningene 2025: Nasjonal strategi for kvalitet og samarbeid i lærerutdanningen. Oslo: Kunnskapsdepartementet.

Kvale, S. \& Brinkmann, S. (2009). Det kvalitative forskningsintervju. 2. utg. Oslo: Gyldendal Akademisk.

Landro, J. \& Støen Utvær, B.K. (2010). Framtidig avgang og nåværende kvalifiseringsbehov blant yrkesfaglærere i Sør-Trøndelag. Trondheim: NTNU, Program for lærerutdanning.

Mausethagen. J-C. \& Smeby, S. (2017). Kvalifisering til profesjonell yrkesutøvelse. Oslo: Universitetsforlaget.

Meld. St. 20 (2012-2013). På rett vei: Kvalitet og mangfold $i$ fellesskolen. Oslo: Kunnskapsdepartementet.

Meld. St. 28 (2015-2016). Fag - Fordypning - Forståelse: En fornyelse av Kunnskapsløftet. Oslo: Kunnskapsdepartementet.

NIFU. (2015). Yrkesutdanninger med svak forankring i arbeidslivet: En kunnskapsoppsummering. NIFU-rapport 2015:16. Oslo: Nordisk institutt for studier av innovasjon, forskning og utdanning (NIFU).

Nilsen, E.N. \& Haaland, G. (2013). Læring gjennom praksis: Innhold og arbeidsmåter i yrkesopplæringen. Oslo: PEDLEX. 
Utfordringer og muligheter i møtepunktet mellom yrkesfaglærerutdanningen og praksis

NOU 2008:18. Fagopplæring for framtida. Oslo: Kunnskapsdepartementet.

Nyen, T. \& Hagen, A. (2012). Fleksibilitet eller faglighet? En studie av innføringen av faget prosjekt til fordypning i Kunnskapsløftet. Fafo-rapport 4. Oslo: Fafo.

Patton, M.Q. (2015). Qualitative research \& evalutation methods. California: SAGE Publications.

Postholm, M.B. (2005). Kvalitativ metode: En innføring med fokus på fenomenologisk, etnografisk og kasusstudier. Oslo: Universitetsforlaget.

Schön, D. (1987). Educating the reflective practitioner. New York: Basic Books.

Sjøberg, S. (2001). Fagdebatt: Fagdidaktikkens innføring i sentrale skolefag. Oslo: Gyldendal Akademisk.

St.meld. nr. 11 (2008-2009). Læreren: Rollen og utdanningen. Oslo: Kunnskapsdepartementet.

Sund, G.H. (2005). Forskjellighet og mangfold: Muligheter eller begrensninger for individ og arbeidsplass? PhD-thesis. Roskilde: Roskilde Universitetscenter.

Sylte, A.L. (2016). Profesjonspedagogikk: Profesjonsretting / yrkesretting av pedagogikk og didaktikk (2. utg.). Oslo: Gyldendal Akademisk.

Sylte, A.L. (2017). Didaktiske prinsipper for relevant yrkes- og profesjonsutdanning. HiOA. Avhandlinger 2017 nr. 11. Oslo: Høgskolen i Oslo og Akershus.

Sylte, A.L. \& Jahanlu, D. (2017). Profesjonsrettet lærerutdanning for yrkesfag: Dagens undervisning og opplevelse av relevans. Scandinavian Journal of Vocations in Development, 2.

Sylte, A.L. (2018). Profesjonsretting og studentaktivitet. Scandinavian Journal of Vocations in Development, 3.

Terum, L.I. \& Smeby, J-C. (2014). Akademisering, kvalitet og relevans. I. N. Frølich, E. Hovdhaugen \& L.I. Terum (Red.), Kvalitet, kapasitet \& relevans: Utviklingstrekk i norsk høyere utdanning (s. 114-139). Oslo: Cappelen Damm akademisk.

Utdanningsdirektoratet. (2006). Læreplan i felles programfag $i$ Vg1 design og håndverk. Oslo: Utdanningsdirektoratet.

Utdanningsdirektoratet. (2016). Forskrift om yrkesfaglig fordypning. Oslo: Utdanningsdirektoratet.

Utdanningsdirektoratet. (2018). Ny tilbudsstruktur og nye læreplaner på yrkesfag. Hentet 03. november 2018 fra: https://www.udir.no/laring-og-trivsel/lareplanverket/under-arbeid/ny-tilbudsstruktur-og-nye-lareplaner-pa-yrkesfag/

Vibe, N., Frøseth, M.W., Hovdhaugen, E. \& Markussen, E. (2012). Strukturer og konjukturer: Evaluering av Kunnskapsløftet: Sluttrapport fra prosjektet "Tilbudsstruktur, gjennomføring og kompetanseoppnåelse". Oslo: NIFU.

Young, M. (2004). Conseptualizing vocational knowledge: Some theoretical considerations. I H. Rainbird, A. Fuller \& A. Munro (Red.), Workplace learning in context (s. 186-200). London: Routledge. 